\title{
Ativação de células de memória na produção de anticorpos e na expressão de células IgM positivas no baço de tilápias-do-nilo
}

[Activation of memory cells in the antibody production and the expression of IgM positive cells in Nile tilapia spleen]

\author{
S.F. Eto ${ }^{1}$, D.C. Fernandes ${ }^{2}$, M.C. Rosolem ${ }^{1}$, F.A. Marinho-Neto ${ }^{1}$, J.M. Pizauro ${ }^{1,2}$, R. Salvador ${ }^{3}$, \\ J.R.E. Moraes ${ }^{1}$, F.R. Moraes ${ }^{1}$
}

${ }^{1}$ Universidade Estadual Paulista Júlio de Mesquita Filho - Jaboticabal, SP
${ }^{2}$ Universidade Estadual Paulista Júlio de Mesquita Filho - Araraquara, SP
${ }^{3}$ Universidade Estadual do Norte do Paraná - Bandeirantes, PR

\section{RESUMO}

O presente trabalho avaliou o papel do baço no armazenamento e na reativação das linhagens de células $\mathrm{B}$, representadas por células IgM positivas imunomarcadas no tecido esplênico, bem como a funcionalidade dessas células, sobre a cinética dos linfócitos e na produção sistêmica de anticorpos em tilápias-do-nilo (Oreochromis niloticus). Foram separados dois grupos: grupo memória, constituído por peixes previamente imunizados com hemácia de carneiro a $2,5 \%$, para a geração da memória imune, e o grupo naive, que recebeu o mesmo volume de solução salina a $0,65 \%$. Após 32 dias, os dois grupos foram submetidos a uma nova dose do antígeno na mesma concentração, volume e via de inoculação. A reativação dos clones de memória foi evidenciada pelo aumento do número de células IgM positivas no baço do grupo memória no dia zero/pré-imune. Além disso, o mesmo grupo apresentou aumento dos títulos de anticorpos séricos no $14^{\circ}$ dia e no número absoluto de linfócitos no $21^{\circ}$ dia em relação ao grupo naive. Esses resultados sugerem que o baço não seja apenas um local de armazenamento, mas também de reativação de células $\mathrm{B}$ de memória em tilápia-do-nilo.

Palavras-chave: teleósteo, imunologia, imunoglobulina M, vacina

\begin{abstract}
This work aimed to evaluate the role of the spleen in storage and reactivation of the memory B cells, represented by IgM positive cells and the systemic production of sheep antibodies anti-red cell in Nile tilapia (Oreochromis niloticus). Two groups were established: the memory group, containing fish previously immunized with a 2,5\% sheep anti-red cell, to generate the immune memory; and the naive group, containing fish that received a 0,65\% saline solution. After 32 days, both groups were subjected to a new dose of the same antigen at the same concentration, volume, and inoculation via. The memory clones reactivation was correlated to the increase of the IgM positive cells in the spleen in the memory group at 0 day. The memory group showed an increase in the absolute number of lymphocytes at 21 days and an increase in the antibodies at 14 days after inoculation when compared to the naive group. The results suggest that the spleen may be a storage and reactivation place of memory B cells in Nile tilapia.
\end{abstract}

Keywords: teleost, immunology, immunoglobulin $M$, vaccine

\section{INTRODUÇÃO}

A resposta imune humoral tem como função primordial a ativação e expansão de clones específicos de células T e B e o armazenamento de parte dos clones como células de memória na

Recebido em 4 de abril de 2016

Aceito em 12 de abril de 2017

E-mail: silaseto@hotmail.com medula óssea (Fernandes et al., 2015). A eficácia do método de vacinação, pelo menos em parte, está na dependência direta da ativação das células $\mathrm{T}$ e $\mathrm{B}$ de memória, que são responsáveis pela produção e secreção basal de anticorpos específicos para diversos antígenos naturais ou vacinais (Bergljot, 2010). Em mamíferos, após a eliminação do antígeno, partes das células T e B, 
geradas na expansão clonal, migram para a medula óssea e residem no tecido como células de memória (Eto et al., 2012).

Os peixes teleósteos, apesar de não possuírem medula óssea, são constituídos por órgãos linfoides primários, como o timo, o rim cefálico e o caudal, e outros secundários, como as brânquias, o intestino e o baço, que é estruturalmente e funcionalmente análogo ao encontrado nos mamíferos (Ye et al., 2011). O rim cefálico/anterior é predominantemente hematopoiético, enquanto no caudal/posterior predomina a função filtrante, pelo aumento das ultraestruturas glomerulares e tubulares (Kaattari et al., 2002).

O baço tem maior capacidade de produção de anticorpos, sendo responsável também pela hemocaterese (Fernandes et al., 2015). Células $\operatorname{IgM}^{+}$(IgM positivas) foram descritas no baço, nos rins cefálico e caudal de teleósteos, o que sugere que esses dois órgãos sejam sítios de armazenamento de células de memória e, por conseguinte, confirma a relação funcional com a medula óssea de mamíferos (Kaattari et al., 2002).

A ativação das células $\mathrm{B}$ e $\mathrm{T}$ naive e de memória para determinado antígeno é relevante para a geração e a manutenção da resposta vacinal e posterior proteção do hospedeiro a patógenos e toxinas. Portanto, este trabalho teve como objetivo avaliar o potencial da resposta esplênica em peixes teleósteos, por meio da função do órgão no armazenamento e na manutenção de células $\mathrm{B}$ ativas/plasmócitos, naive e dos clones de memória, mediante a expressão de células $\mathrm{IgM}^{+}$no tecido e a participação delas na cinética sistêmica dos linfócitos e na produção de anticorpos séricos.

\section{MATERIAL E MÉTODOS}

Este estudo foi aprovado pela Comissão de Ética no Uso de Animais (Ceua) da Faculdade de Ciências Agrárias e Veterinárias, Unesp, câmpus de Jaboticabal, sob o protocolo número $17205 / 15$. Foram utilizadas 60 tilápias-do-nilo $(80,71 \pm 10,52 \mathrm{~g})$, mantidas em 10 aquários de vidro de $90 \mathrm{~L}(\mathrm{n}=6)$, com fluxo contínuo de água de poço artesiano, livre de cloro, vazão de $1 \mathrm{~L} / \mathrm{min}$, e aeração constante. Os peixes foram alimentados com ração comercial (suplementadas $3 \%$ do peso vivo, $28 \%$ de proteína digestível e $4.000 \mathrm{kcal}$ de energia digestiva $/ \mathrm{kg}$ ). A qualidade da água permaneceu na faixa adequada ao conforto dos peixes (oxigênio dissolvido $=6,1 \pm 1,6 \mathrm{mg} / \mathrm{L}$; temperatura $=28,37 \pm 3,8^{\circ} \mathrm{C} ; \mathrm{pH}=6,96 \pm 1,2 ;$ e condutividade elétrica $=120,96 \pm 16,3 \mu \mathrm{S} / \mathrm{cm})$ e os parâmetros foram mensurados com o aparelho multiparâmetro AK87 (Boyd, 1990).

Após aclimatação por 21 dias, os peixes foram distribuídos em delineamento inteiramente ao acaso, em dois grupos $(n=30)$. Para a formação do grupo memória (GM), 30 peixes foram injetados com solução de hemácia de carneiro (HC) a 2,5\%, em 0,15M de tampão fosfato-salino (PBS) esterilizado ( $\mathrm{pH} 7,2$ ), na dose de $250 \mu \mathrm{L}$ por peixe, via celomática, para a geração prévia da resposta imune humoral e formação dos clones de memória. Já o grupo naive (GN) foi injetado apenas com solução salina $0,65 \%$, com o mesmo volume e via de inoculação que o GM, tendo como objetivo a não formação de resposta imune humoral. Após 32 dias, ambos os grupos receberam uma dose de $\mathrm{HC}$. Os tempos de coleta iniciaram-se no dia anterior à segunda dose, o qual representou o tempo zero, pré-imune, e depois no sétimo, 14, 21 e $28^{\circ}$ dia. Nos tempos predeterminados, os peixes foram anestesiados em banho de solução de benzocaína (1:20.000) diluída em álcool $\quad 98^{\circ} \mathrm{GL} \quad(0,1 \mathrm{~g} / \mathrm{mL})$ (Wedemeyer, 1970), até o quarto estágio de anestesia (Woody et al., 2002). O sangue de cada peixe foi coletado por punção do vaso caudal $(n=7)$ e os peixes foram eutanasiados por aprofundamento anestésico e para a coleta do baço $(n=5)$ para as avaliações nos tempos supracitados.

Para o preparo do inóculo de $\mathrm{HC}$, inicialmente coletaram-se $10 \mathrm{~mL}$ de sangue de carneiro, que foram transferidos para tubos graduados de $50 \mathrm{~mL}$ contendo solução de Alsever (v/v). Em seguida, estes foram centrifugados a $250 \mathrm{~g}$, durante $10 \mathrm{~min}$. O sobrenadante foi descartado, e as hemácias foram ressuspendidas em PBS $0,15 \mathrm{M}(\mathrm{pH} 7,2)$ esterilizado; logo após, a solução foi centrifugada novamente durante cinco minutos. A lavagem foi repetida até a remoção total da hemólise, observada pela ausência da coloração vermelha no sobrenadante. Após o término, a suspensão de hemácias foi diluída na concentração de 2,5\% em PBS 0,15M (pH 7,2) esterilizado. A suspensão de hemácias foi 
armazenada para imunização dos peixes e para o teste de hemaglutinação direta, mantida a $4^{\circ} \mathrm{C}$ até ao momento da sua utilização.

O teste de aglutinação direta foi realizado de acordo com Fernandes et al. (2015). As amostras de soro dos peixes foram desativadas a $47^{\circ} \mathrm{C}$, durante 30min, em banho-maria. Em seguida, foi realizada a diluição seriada de $\log _{2}$ dessas amostras, em placas de microtitulação. Foram adicionados $50 \mu \mathrm{L}$ de PBS $0,15 \mathrm{M}$ (pH 7,2) esterilizado em todos os poços e, a seguir, $50 \mu \mathrm{L}$ de plasma desativado no primeiro poço da placa. Em seguida, realizaram-se a homogeneização da solução e a transferência de $50 \mu \mathrm{L}$ para o orifício seguinte, repetindo-se o processo até o $11^{\circ}$ poço, onde o mesmo volume da solução foi desprezado. Esse procedimento foi realizado para todas as amostras de plasma da avaliação préimune e no sétimo, 14, 21 e $28^{\circ}$ dias. Em seguida, foi adicionado volume igual do inóculo de $\mathrm{HC}$ a $2,5 \%$ em cada poço, e a placa incubada por uma hora, a $37^{\circ} \mathrm{C}$, e 22 horas a $4^{\circ} \mathrm{C}$. Após esse período, foi realizada a leitura visual das placas, comparando-se o padrão de sedimentação do poço controle sem plasma $\left(12^{\circ}\right.$ poço), com os padrões de sedimentação dos demais. O título de anticorpos totais foi identificado como a maior diluição em que foi possível observar aglutinação positiva das hemácias. Os resultados foram expressos no $\log _{2}$ dos recíprocos dos títulos dos soros, e os dados processados submetidos à análise estatística.

Os perfis hematológico e bioquímico foram avaliados durante todo o percurso da resposta imune humoral. Inicialmente, a porcentagem do hematócrito foi determinada usando tubos de micro-hematócrito e a escala de hemoconcentração (volume globular) (Goldenfarb et al., 1971). A concentração de proteínas plasmáticas totais (PPT) foi quantificada pelo método utilizando a solução de biureto ( $545 \mathrm{~nm}$ de comprimento de onda). $\mathrm{Na}$ contagem dos leucócitos totais, utilizou-se a câmara de Neubauer (Martins et al., 2009), e a contagem dos linfócitos absolutos foi realizada em extensão sanguínea corada com a coloração de May-Grunwald-Giemsa-Wright (Tavares-Dias e Moraes, 2007). A determinação da concentração de albuminas totais (Alb) foi realizada no soro pelo método colorimétrico, com o uso de kit comercial (Albumina Monoreagente-K040, Bioclin, BR). A concentração de imunoglobulinas totais $(\mathrm{Ig})$ foi calculada e determinada por meio da subtração do valor da albumina do valor da concentração de proteínas totais, tendo como resultado a expressão do valor das imunoglobulinas totais.

Para a avaliação da resposta esplênica, por meio da expressão de células $\operatorname{IgM}^{+}$, fragmentos de baço dos peixes foram processados para obtenção de cortes semisseriados de $3 \mu \mathrm{m}$ de espessura, que foram depositados em lâminas de vidro, polarizadas, e desparafinados. A recuperação antigênica foi feita por calor em panela do tipo Pascal (Dako, USA), com solução tampão Tris EDTA (pH 7,4), durante 30 minutos. Seguiu-se o bloqueio da peroxidase endógena com solução comercial (Hydrogen Peroxide Block, Spring, cod. DHP-060, UK) e um banho em tampão Tris HCL (pH 7,4), durante cinco minutos.

Um novo bloqueio da peroxidase fora realizado, com água oxigenada (30 vol.) e álcool metílico (solução final a 10\%). O bloqueio das reações inespecíficas (Protein Block, Spring, cod. DPB060, UK), foi realizado por uma hora, em câmara úmida e em temperatura ambiente, seguido de

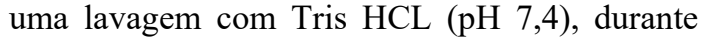
cinco minutos. Em seguida, foi realizado novo bloqueio das proteínas inespecíficas, com leite em pó $\left(\right.$ Molico $^{\circledR}, \mathrm{BR}, 2 \mathrm{~g}$ para cada $25 \mathrm{~mL}$ de água destilada), por uma hora, em câmara úmida e em temperatura ambiente.

A incubação do anticorpo primário foi a $4{ }^{\circ} \mathrm{C}$, durante 18 horas, em câmara úmida, na diluição de 1:2.000 (rabbit polyclonal antibody to human IgM, DBS, cod. RP024, UK) e aplicação do substrato (REVEAL - Biotin Free Polyvalent AP (RED), cod. PAR-060, UK), com incubação do HRP-link, por 10 minutos, seguido da aplicação do polímero, por 30 minutos, em temperatura ambiente, sem lavagem entre eles. Para a visualização da reação, utilizou-se o cromógeno diaminobenzidina (DAB) (Spring, 3,3'diaminobenzidina - cod. DAB-060, CA). Para o controle positivo, foi utilizada tonsila humana e, para o controle negativo, foi utilizado baço de peixe, sem a injeção de $\mathrm{HC}$, a 2,5\%. A contracoloração foi realizada com hematoxilina de Harris, e a montagem das lâminas com Permount (Fisher Scientific, cod. S70104, CA). 
A contagem das células imunomarcadas foi realizada sob microscopia de luz, com equipamento para fotomicrografia digital (Nikon E200, BR). Para a quantificação, foram escolhidos, aleatoriamente, cinco campos, onde foi contabilizado o número total de células marcadas, na objetiva de 40x.

Todos os resultados foram submetidos à análise de variância e à comparação de médias pelo teste de Tukey $(\mathrm{P}<0,05)$, ao nível de significância de 5\% (Snedecor e Cochran, 1974).

\section{RESULTADOS}

A avaliação da resposta esplênica por imunohistoquímica qualitativa resultou na imunomarcação de células $\operatorname{IgM}^{+}$, o que permitiu, por meio da análise morfológica, distinguir dois estágios celulares distintos (Fig. 1A) plasmócitos (Fig. 1B) e célula $\mathrm{B}$ não ativada/naive ou de memória (Fig. 1C). As células $\operatorname{IgM}^{+}$foram visualizadas em todas as amostras e grupos analisados. Entretanto, quando as células $\operatorname{IgM}^{+}$ foram quantificadas, o GM obteve um aumento significativo $(\mathrm{P}<0,05)$ comparado ao $\mathrm{GN}$ no período pré-imune, representado pelo dia zero (Fig. 1D).

Quando a resposta imune humoral dos grupos foi avaliada, ambos os grupos mostraram-se capazes de reconhecer e produzir anticorpos reativos para os antígenos presentes nas HC. Porém, a intensidade da resposta foi divergente entre os grupos (Fig. 1E). O GM, apesar de não significativo, apresentou títulos de anticorpos séricos no período pré-imune. $\mathrm{O}$ mesmo grupo apresentou aumento significativo $(\mathrm{P}<0,05) \mathrm{em}$ relação ao $\mathrm{GN}$ no $14^{\circ}$ dia do protocolo imunização.

Os valores hematológicos e bioquímicos não apresentaram diferença estatística significativa entre os grupos durante o período experimental (Tab. 1). O leucograma do GM apresentou aumento significativo $(\mathrm{P}<0,05)$ do número total de leucócitos no $21^{\circ}$ dia após o início do protocolo em relação ao GN (Tab. 1). A análise diferencial demonstrou que a leucocitose foi representada em parte pelo aumento do número absoluto dos linfócitos do GM em relação ao naive no mesmo período de análise (Fig. 1F).
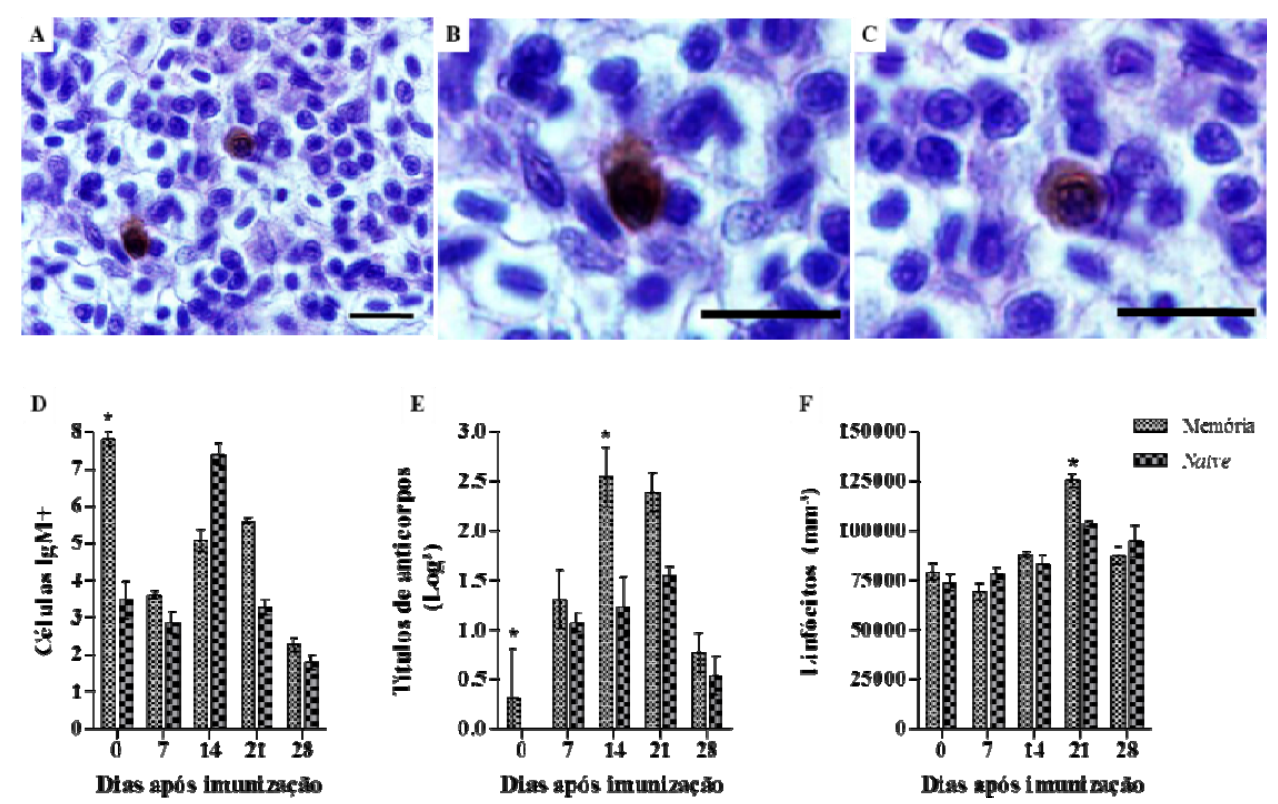

Figura 1. A) Fotomicrografia de fragmento de baço com imunomarcação positiva para células produtoras de IgM reveladas com (DAB). B) Célula IgM+ com núcleo periférico e citoplasma abundante. C) Célula IgM+, núcleo central e pouco citoplasma. Hematoxilina de Harris. Barra: $10 \mu \mathrm{m}$. D) Número de células $\operatorname{IgM}^{+}$. E) Resposta humoral. F) Cinética da resposta linfocitária em tilápias-do-nilo ( $\mathrm{n}=7)$, inoculadas com HC. Cada ponto representa a média \pm erro padrão observados nos grupos naive e memória. *Diferença significativa pelo teste de Tukey $(\mathrm{P}<0,05)$. DAB: diaminobenzidina; HE: hemácia de carneiro. 
Ativação de células...

Tabela 1. Perfil hematológico e imune humoral de tilápias-do-nilo inoculadas com HC

\begin{tabular}{|c|c|c|c|c|c|c|}
\hline & \multirow{2}{*}{ Tratamento } & \multicolumn{5}{|c|}{ Tempo (dias) } \\
\hline & & 0 (pré-imune) & 7 & 14 & 21 & 28 \\
\hline \multirow{2}{*}{ VG (\%) } & Naive & $26,3 \pm 1,5 \mathrm{~A}$ & $27,5 \pm 0,9 \mathrm{~A}$ & $24,4 \pm 1,4 \mathrm{~A}$ & $26,5 \pm 0,9 \mathrm{~A}$ & $26,9 \pm 1,3 \mathrm{~A}$ \\
\hline & Memória & $28,1 \pm 1,1 \mathrm{~A}$ & $27,3 \pm 1,7 \mathrm{~A}$ & $27,2 \pm 0,8 \mathrm{~A}$ & $30,6 \pm 0,3 \mathrm{~A}$ & $24,6 \pm 1,3 \mathrm{~A}$ \\
\hline \multirow{2}{*}{ PPT (g/dl) } & Naive & $3,4 \pm 0,1 \mathrm{~A}$ & $3,8 \pm 0,2 \mathrm{~A}$ & $3,9 \pm 0,1 \mathrm{~A}$ & $4,3 \pm 0,2 \mathrm{~A}$ & $3,9 \pm 0,1 \mathrm{~A}$ \\
\hline & Memória & $3,3 \pm 0,1 \mathrm{~A}$ & $3,9 \pm 0,2 \mathrm{~A}$ & $3,8 \pm 0,1 \mathrm{~A}$ & $4,4 \pm 0,3 \mathrm{~A}$ & $3,8 \pm 0,1 \mathrm{~A}$ \\
\hline \multirow{2}{*}{ Albumina (g/dl) } & Naive & $0,7 \pm 0,0 \mathrm{~A}$ & $0,8 \pm 0,0 \mathrm{~A}$ & $1,1 \pm 0,0 \mathrm{~A}$ & $1,1 \pm 0,0 \mathrm{~A}$ & $1,0 \pm 0,0 \mathrm{~A}$ \\
\hline & Memória & $0,7 \pm 0,0 \mathrm{~A}$ & $0,9 \pm 0,0 \mathrm{~A}$ & $1,1 \pm 0,0 \mathrm{~A}$ & $1,0 \pm 0,0 \mathrm{~A}$ & $1,0 \pm 0,0 \mathrm{~A}$ \\
\hline \multirow{2}{*}{ Imunoglobulina (g/dl) } & Naive & $2,7 \pm 0,1 \mathrm{~A}$ & $2,9 \pm 0,1 \mathrm{~A}$ & $2,9 \pm 0,1 \mathrm{~A}$ & $3,2 \pm 0,2 \mathrm{~A}$ & $2,9 \pm 0,2 \mathrm{~A}$ \\
\hline & Memória & $2,5 \pm 0,1 \mathrm{~A}$ & $3,0 \pm 0,1 \mathrm{~A}$ & $2,7 \pm 0,1 \mathrm{~A}$ & $3,4 \pm 0,3 \mathrm{~A}$ & $2,7 \pm 0,1 \mathrm{~A}$ \\
\hline \multirow{2}{*}{ Anticorpos Totais (\%) } & Naive & $0,0 \pm 0,0 \mathrm{~A}$ & $1,0 \pm 0,3 \mathrm{~A}$ & $1,2 \pm 0,3 \mathrm{~A}$ & $1,5 \pm 0,2 \mathrm{~A}$ & $0,5 \pm 0,2 \mathrm{~A}$ \\
\hline & Memória & $0,3 \pm 0,2 \mathrm{~A}$ & $1,3 \pm 0,1 \mathrm{~A}$ & $2,5 \pm 0,3 \mathrm{~A}$ & $2,3 \pm 0,1 \mathrm{~A}$ & $0,7 \pm 0,2 \mathrm{~A}$ \\
\hline \multirow{2}{*}{$\begin{array}{l}\text { Leucócitos Totais } \\
(\text { número/ } \mu \mathrm{L})\end{array}$} & Naive & $\begin{array}{l}98890,0 \pm \\
4909,0 \mathrm{~A}\end{array}$ & $\begin{array}{c}93984,0 \pm \\
2413,0 \mathrm{~A}\end{array}$ & $\begin{array}{c}95722,0 \pm \\
4629,0 \mathrm{~A}\end{array}$ & $\begin{array}{c}122056,0 \pm \\
8306,0 \mathrm{~B}\end{array}$ & $\begin{array}{c}120692,0 \pm \\
4599,0 \mathrm{~A}\end{array}$ \\
\hline & Memória & $\begin{array}{l}97240,0 \pm \\
3675,0 \mathrm{~A}\end{array}$ & $\begin{array}{c}103488,0 \pm \\
3512,0 \mathrm{~A}\end{array}$ & $\begin{array}{c}103752,0 \pm \\
1313,0 \mathrm{~A}\end{array}$ & $\begin{array}{l}175154,0 \pm \\
3650,0 \mathrm{~A}\end{array}$ & $\begin{array}{c}114724,0 \pm \\
1215,0 \mathrm{~A}\end{array}$ \\
\hline \multirow{2}{*}{$\begin{array}{l}\text { Linfócitos absolutos } \\
\text { (número/ } / \mathrm{L} \text { ) }\end{array}$} & Naive & $\begin{array}{l}73526,0 \pm \\
4077,4 \mathrm{~A}\end{array}$ & $\begin{array}{l}77830,0 \pm \\
3773,9 \mathrm{~A}\end{array}$ & $\begin{array}{l}83052,0 \pm \\
4997,1 \mathrm{~A}\end{array}$ & $\begin{array}{c}103660,0 \pm \\
7872,9 \mathrm{~B}\end{array}$ & $\begin{array}{c}94518,0 \pm \\
4608,9 \mathrm{~A}\end{array}$ \\
\hline & Memória & $\begin{array}{l}79213,0 \pm \\
4283,5 \mathrm{~A}\end{array}$ & $\begin{array}{l}69246,0 \pm \\
4285,4 \mathrm{~A}\end{array}$ & $\begin{array}{c}88071,0 \pm \\
1553,5 \mathrm{~A}\end{array}$ & $\begin{array}{c}125260,0 \pm \\
3346,2 \mathrm{~A}\end{array}$ & $\begin{array}{l}87482,0 \pm \\
9231,1 \mathrm{~A}\end{array}$ \\
\hline
\end{tabular}

Médias $(\mathrm{n}=7)$ com os respectivos erro padrão, letras maiúsculas comparam a coluna entre os grupos em cada período de tempo experimental. Letras maiúsculas distintas se diferem pelo teste Tukey $(\mathrm{p}>0,05)$. HC-Hemácia de Carneiro; VG - Volume Globular; PPT - Proteína Plasmática Total.

\section{DISCUSSÃO}

A ativação das respostas imune humoral ou celular em teleósteos, seja por infecção natural, experimental ou profilática, estará sempre sob a regência e interdependência estrutural, organizacional e funcional dos órgãos e tecidos linfoides primários e secundários. As células $\mathrm{B}$ e $\mathrm{T}$ orquestram a resposta imune adquirida em nível celular e molecular e são amplamente distribuídas para a corrente sanguínea e os órgãos secundários, como intestino (Zapata et al., 2006), pele (Wölfle et al., 2009) e brânquias, participando ativamente na resposta imune humoral (Von et al., 2011). O baço é o principal órgão linfoide secundário em teleósteos, responsável pela atividade de hemocaterese e pela produção de anticorpos, análogo funcionalmente ao baço dos mamíferos e a outros vertebrados superiores, sendo ativamente compensatório à ausência de nódulo ou sistema linfoide nessa espécie (Zapata et al., 2006; Salinas et al., 2011).

As células $\operatorname{IgM}^{+}$surgem no baço 26 dias após a eclosão e aumentam progressivamente até 102 dias, durante o processo ontogenético dessas células em peixe-mandarim Siniperca chuatsi
(Tian et al., 2009). Esse fato prova a preexistência de células $\operatorname{IgM}^{+}$no baço em um estado imunofisiológico, observado no GN. Contrário a isso, o aumento do número dessas células no GM no período pré-imune gera supostas evidências de que esse número distinto e elevado de células $\operatorname{IgM}^{+}$no baço possa ser clone da primeira expansão gerada 32 dias anteriores à análise. A diferenciação entre os estágios de maturação das células B estudadas foi possível por meio da análise morfológica, que diferenciou as células $\mathrm{B}$ ativadas/plasmócitos das não ativadas. Entretanto, toda a linhagem de células B é $\operatorname{IgM}^{+}$, e essas podem ser detectadas na forma de receptor acoplado à membrana ou contidas em vesículas secretoras citoplasmáticas de plasmócitos ativados (Kaattari et al., 2002).

Ye et al. (2011) descreveram um modelo de diferenciação, recirculação e distribuição das células B em teleósteos, dividindo as células B em três fenótipos celulares distintos: naive, ativados/plasmócitos e de memória, residentes na circulação sanguínea, no baço, nos rins posterior e anterior, sendo o último o local de armazenamento das células de memória/longa vida. A residência de um número elevado de células $\operatorname{IgM}^{+}$no baço, após 32 dias da primeira 
dose no GM, levanta a hipótese de que parte dessas células da linhagem B sejam de memória, geradas na primeira expansão clonal, o que indica um possível sítio de permanência de plasmócitos ativados e também células $\mathrm{B}$ de memória.

$\mathrm{O}$ aumento do número de células $\operatorname{IgM}^{+}$no baço do GM, no período pré-imune, sugere que essas células sejam compostas por plasmócitos e células $\mathrm{B}$ reativas e de memória, gerados na primeira expansão clonal. Indica também que as mesmas células foram, em parte, responsáveis pela produção basal de anticorpos séricos antihemácia de carneiro, detectados no mesmo período de tempo e grupo, e pelo aumento dos títulos de anticorpos no $14^{\circ}$ dia e do número absoluto dos linfócitos no $21^{\circ}$ dia após o inóculo no GM. O mecanismo proposto de ativação das linhagens de células B no baço está ilustrado e esquematizado na Fig. 2.
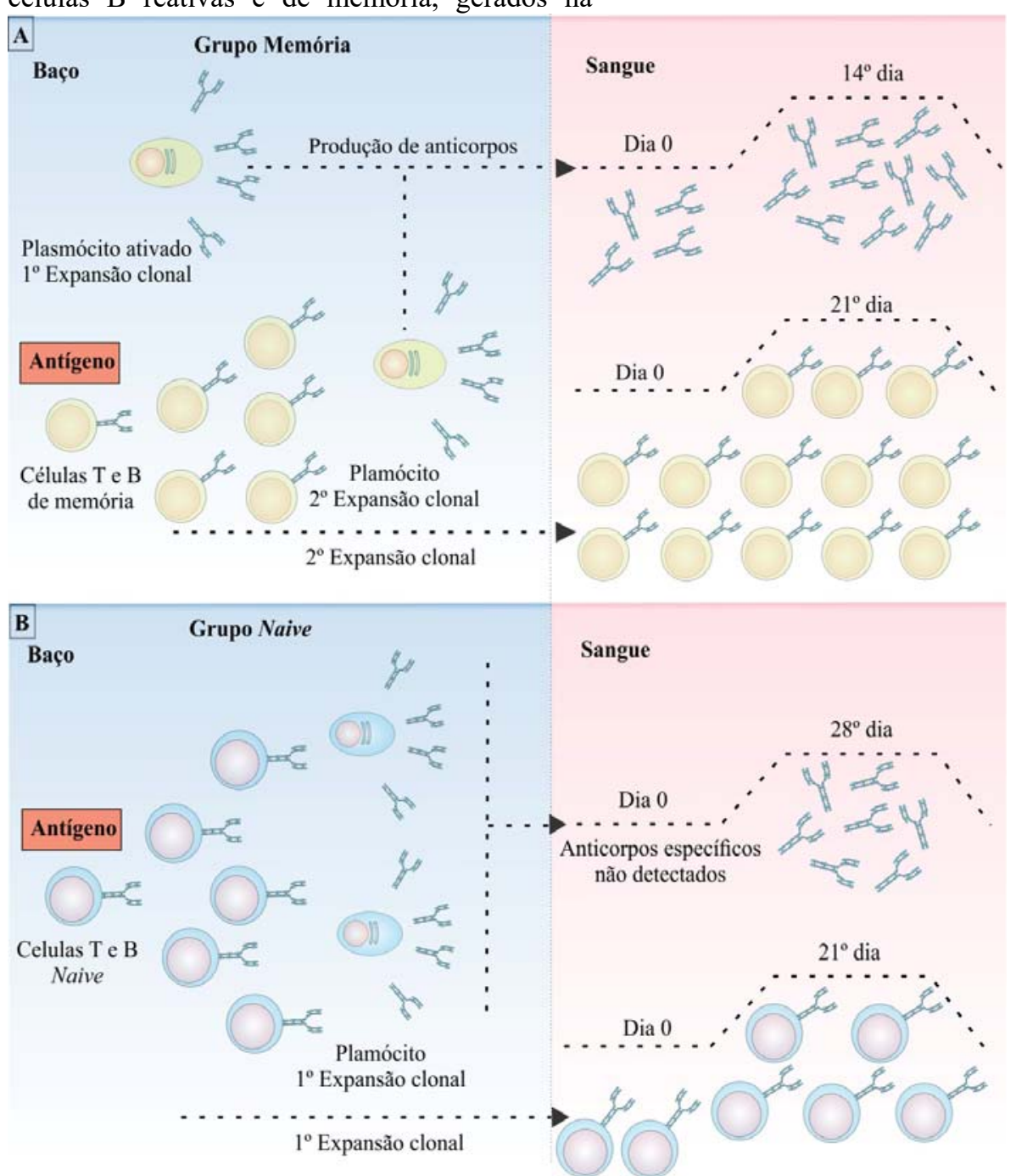

Figura 2. Mecanismo de ativação das células de memória no baço de tilápias-do-nilo, imunizadas com HC. (A) Plasmócitos ativados gerados na primeira expansão clonal (ExC), responsável pela produção basal de anticorpo no pré-imune e total durante a cinética da resposta humoral. Reativação das células de memória, geradas no primeiro estímulo imunogênico, resultando no aumento dos anticorpos no $14^{\circ}$ dia e dos linfócitos sanguíneos no $21^{\circ}$ dia após o segundo estímulo. Observar que a segunda ExC no GM foi detectada na corrente sanguínea no $21^{\circ}$ dia, o que prova que o aumento dos títulos de anticorpos no $14^{\circ}$ dia foi produzido pela primeira geração de clones. (B) Baço $\mathrm{GN}$, ativação da primeira geração de clones, aumento da produção de anticorpos no $28^{\circ}$ dia e de linfócitos sanguíneos no $21^{\circ}$ dia. 
Castro et al. (2013) investigaram o papel do baço na resposta imune humoral e a expressão de genes relacionados à fração constante $(\mathrm{Fc})$ das imunoglobulinas da classe $\operatorname{IgM}$, IgD e IgT, em trutas arco-íris, desafiadas com cepas desativadas de Rhabdovírus. Os autores observaram um aumento expressivo da classe IgM e IgT durante o percurso da infecção experimental. No presente estudo, os níveis de anticorpos específicos, aumentaram progressivamente durante todo o protocolo de imunização. A atividade aglutinante no ensaio de aglutinação direta prova que, além da expressão em nível cromossômico, como relatado pelos autores supracitados, a imunoglobulina é também funcional, sintetizada e secretada na circulação sistêmica.

O conceito da reativação das células de memória após um segundo estímulo antigênico e seus efeitos no aumento da produção de anticorpos e no número absoluto de linfócitos circulantes foram descritos em teleósteos inoculados com $\mathrm{HC}$, sendo observado o aumento desses parâmetros no $21^{\circ}$ dia após a segunda dose comparada a uma única dose em tilápias-do-nilo (Fernandes et al., 2015). O padrão cinético das respostas humoral e celular foi semelhante ao do estudo prescrito acima. Porém, os resultados fornecidos pelo atual estudo possibilitaram analisar o nível da resposta esplênica e seu efeito sobre a produção de anticorpos e na expansão dos clones de células $\mathrm{B}$ e $\mathrm{T}$ de memória na circulação sanguínea. Rombout et al. (2011) descreveram que entre $30-40 \%$ dos linfócitos circulantes são fenótipos de células $B$, o que possibilita afirmar que parte do número de linfócitos circulantes observados no $21^{\circ}$ dia seja composto, em sua maioria, por células $\mathrm{B}$.

O baço apresentou aspectos funcionais importantes na geração e manutenção de células residentes ativas e de memória, detectadas 32 dias após a primeira dose no GM por meio dos níveis basais de anticorpos e do número absoluto de linfócitos. Esses resultados colaboram para o entendimento da cinética da resposta esplênica e, consequentemente, da resposta imune humoral em teleósteos, o que abre novas perspectivas para a profilaxia de doenças nessa espécie.

\section{CONCLUSÕES}

O conjunto de informações obtidas no presente estudo permite a implantação de protocolos mais eficazes para a imunização de matrizes ou reprodutores de alto valor zootécnico, a fim de reduzir o estresse, prolongar o intervalo entre doses e aumentar a eficácia da resposta imune humoral, por meio da reativação dos clones de memória no baço. Finalmente, a ativação dessas células de memória resulta na produção de anticorpos de alta afinidade, potencializando-se, assim, a resposta vacinal e, consequentemente, o nível de proteção do hospedeiro.

\section{REFERÊNCIAS}

BERGLJOT, M. Immunological control of fish diseases. Mar. Biotechnol., v.12, p.361-379, 2010 .

BOYD, C.E. Water quality in ponds for aquaculture. Alabama: Auburn University, Alabama Agricultural Experiment Station, 1990. $482 \mathrm{p}$.

CASTRO, R.; JOUNEAU, L.; PHAM, H.P. et al. Teleost fish mount complex clonal IgM and IgT responses in spleen upon systemic viral infection. Plos Pathog., v.9, p.1-18, 2013.

ETO, S.F.; ANDRADE, F.G.; PINHEIRO, J.W. et al. Effect of inoculation route on the production of antibodies and histological characteristics of the spleen in laying hens. Braz. J. Poult. Sci., v.14, p.63-66, 2012.

FERNANDES, D.C.; ETO, S.F.; CLAUDIANO, G.S. et al. Humoral immune response of Oreochromis niloticus: modified direct agglutination test. Comp. Clin. Pathol., v.24, p.617-623, 2015.

GOLDENFARB, P.; BOWYER, F.P.; HALL, E.; BROSIOUS, E. Reproducibility in the hematology laboratory: the microhematocrit determination. Am. J. Clin. Pathol., v.56, p.3539, 1971.

KAATTARI, S.L.; ZHANG, H.L.; KHOR, I.W. et al. Affinity maturation in trout: clonal dominance of high affinity antibodies late in the immune response. Dev. Comp. Immunol., v.26, p.191-200, 2002. 
MARTINS, M.L.; MIYAZAKI, D.M.Y.; TAVARES-DIAS, M. et al. Characterization of the acute inflammatory response in the hybrid tambacu (Piaractus mesopotamicus male $\mathrm{x}$ Colossoma macropomum female) (Osteichthyes). Braz. J. Biol., v.69, p.957-962, 2009.

ROMBOUT, J.H.; ABELLI, L.; PICCHIETTI, S. et al. Teleost intestinal immunology. Fish Shellfish Immunol., v.31, p.616-626, 2011.

SALINAS, I.; ZHANG, Y.A.; SUNYER, J.O. Mucosal immunoglobulins and B cells of teleost fish. Dev. Comp. Immunol., v.35, p.1346-1365, 2011.

SNEDECOR, G.W.; COCHRAN, G. Statistical methods. Ames: Iowa State University Press, 1974. [593p].

TAVARES-DIAS, M.; MORAES, F.R. Leukocyte and thrombocyte reference values catfish (Ictalurus punctatus Raf), with na assessment of morphologic, cytochemical, and ultrastructural features. Vet. Clin. Pathol., v.36, p.49-54, 2007.

TIAN, J.Y.; XIE, H.X.; ZHANG, Y.A. et al. Ontogeny of IgM-producing cells in the mandarin fish Siniperca chuatsi identified by in situ hybridisation. Vet. Immunol. Immunopathol., v.132, p.146-152, 2009.
VON, G.J.L.; HEINECKE, R.D.; SKJØDT, K. et al. Experimental evidence for direct in situ binding of $\operatorname{IgM}$ and $\operatorname{IgT}$ to early trophonts of Ichthyophthirius multifiliis (Fouquet) in the gills of rainbow trout, Oncorhynchus mykiss (Walbaum). J. Fish. Dis., v.34, p.749-755, 2011.

WEDEMEYER, G. The role of stress in the disease resistance of fishes. Am. Fish. Soc., v.5, p.30-35, 1970.

WÖLFLE, U.; MARTIN, S.; EMDE, M.; SCHEMPP, C. Dermatology in the Darwin anniversary. Part 2: Evolution of the skinassociated immune system. J. Dtsch. Dermatol. Ges., v.7, p.862-869, 2009.

WOODY, C.A.; NELSON, J.; RAMSTAD, K. Clove oil as an anesthetic for adult sockeye salmon: field trials. J. Fish Biol., v.60, p.340347, 2002.

YE, J.; KAATTARI, I.M.; KAATTARI, S.L. The differential dynamics of antibody subpopulation expression during affinity maturation in a teleost. Fish Shellfish Immunol., v.30, p.372-377, 2011.

ZAPATA, A.; DIEZ, B.; CEJALVO, T. et al. Ontogeny of the immune system of fish. Fish Shellfish Immunol., v.20, p.126-136, 2006. 